\title{
Heterogén vastagbéldaganat: a fogazott útvonalon kialakuló, sporadikus laesiók jelentősége a klinikai gyakorlatban
}

\author{
Ágoston Emese Irma dr. ${ }^{1}$ - Horváth Evelin dr. ${ }^{3}$ - Győrffy Balázs dr. ${ }^{4}$ \\ Harsányi László dr. ${ }^{1}$ - Szász A. Marcell dr. ${ }^{2}$ \\ Semmelweis Egyetem, Általános Orvostudományi Kar, ${ }^{1}$ I. Sebészeti Klinika, ${ }^{2}$ Onkológiai Központ, Budapest \\ ${ }^{3}$ Hospital Universitario Son Espases, Palma de Mallorca, Spanyolország \\ ${ }^{4}$ MTA-TTK Lendület Onkológiai Biomarker Munkacsoport, Budapest
}

\begin{abstract}
A colorectalis daganatra ma már igen heterogén betegségként tekintünk, mely heterogenitást a kialakulásában szerepet játszó genetikai faktorok, molekuláris eltérések, különböző jelátviteli útvonalak, valamint mikro- és makrokörnyezeti tényezők okoznak. A korábban ismert „klasszikus” adenoma-carcinoma szekvencia mellett az elmúlt évtizedben egy másik, alternatív útvonal is felismerésre került. Ezt „fogazott” útvonalnak nevezzük, mely az elváltozások kb. egyharmadáért felelős. Ezek a laesiók a molekuláris tulajdonságaikon felül makroszkópos és mikroszkópos képükben és progressziós hajlamukban, illetve prognózisukban is eltérnek a klasszikus útvonal daganataitól. Az alábbi összefoglaló közlemény ezen eltérések molekuláris tulajdonságait, makroszkópos és szövettani jellegzetességeit, illetve klinikai jelentőségét szemlélteti.
\end{abstract}

Orv Hetil. 2018; 159(6): 206-214.

Kulcsszavak: vastagbéldaganat, fogazott útvonal, polip, prognózis

\section{Colorectal cancer heterogeneity: the clinical impact of sporadic lesions arising via the serrated pathway}

\begin{abstract}
Today, colorectal cancer is regarded as a heterogeneous disease. Its heterogeneity is caused by genetic alterations, molecular aberrations, different developing pathways as well as by micro- and macroenviromental agents. In the last decade, beside the classic genetic model for colorectal tumuorgenesis that follows the adenoma-carcinoma sequence, an alternative pathway has been identified. This pathway is called the serrated pathway and it is responsible for approximately one third of all colorectal lesions. Beyond their dissimilar molecular characteristics, these tumours also show different macroscopic and histologic appearance. Moreover, their malignant potency and progressive ability distinguish them from tumours of the classic genetic model. The aim of this review is to summarize the molecular and pathologic features of serrated lesions and the serrated pathway to colorectal cancer and to highlight their clinical impact.
\end{abstract}

Keywords: colorectal cancer, serrated pathway, polyp, prognosis

Ágoston EI, Horváth E, Győrffy B, Harsányi L, Szász AM. [Colorectal cancer heterogeneity: the clinical impact of sporadic lesions arising via the serrated pathway]. Orv Hetil. 2018; 159(6): 206-2014.

(Beérkezett: 2017. október 25.; elfogadva: 2017. november 23.)

\section{Rövidítések}

5-FU = 5-fluorouracil; ANXA10 = annexin-A10; $\mathrm{APC}=($ adenomatous polyposis coli) adenomatosus polyposis; $\mathrm{BRAF}=\mathrm{Raf}$ murin sarcoma virális onkogén homológ $\mathrm{B}$; CEA = carcino- embrionalis antigén; CIMP $=(\mathrm{CpG}$-island methylator phenotype) CpG-sziget-metilációs fenotípus; CIMP-H = magas CpG-sziget-metilációs fenotípus; CIMP-L = alacsony CpG-sziget-metilációs fenotípus; CIN = kromoszomális instabilitás; 
CLDN18 = klaudin-18; CMS = konszenzusmolekuláris altípus; $\mathrm{CRC}=$ colorectalis carcinoma; $\mathrm{c}-\mathrm{Src}=$ protoonkogén tirozin-proteinkináz Src; CSS = daganatspecifikus túlélés; CTSE = katepszin-E; DFS = betegségmentes túlélés; EGFR = epidermális növekedési faktor receptor; HNPCC $=$ herediter nem polyposis colorectalis carcinoma; IFL = irinotekán, fluorouracil, leukovorin; KRAS = Kirsten-patkány-sarcoma virális onkogén homológ; $\mathrm{LV}=$ leukovorin; $\mathrm{MEK}=$ mitogénaktivált proteinkináz; $\mathrm{MMR}=$ mismatch repair (hibás bázispárosodás kijavítása); MSI = mikroszatellita-instabilitás; MSI-H = magas mikroszatellita-instabilitás; MSI-L = alacsony mikroszatellitainstabilitás; MSS = mikroszatellita-stabil; MUC5AC $=$ mucin$5 \mathrm{AC}$, oligomeric mucus/gel-forming; MUC6 = mucin-6, oligomeric mucus/gel-forming; Ras = patkánysarcoma virális onkogén homológ; Raf = rapidly accelerated fibrosarcoma; $\mathrm{RFS}=$ relapsusmentes túlélés; $\mathrm{RR}=$ válaszarány; $\mathrm{SSA} / \mathrm{P}=$ szesszilis fogazott adenoma/polip; OS = teljes túlélés; TCGA = The Cancer Genome Atlas (Rákgenom Atlasz); TFF2 = trefoil factor- 2 ; TNM = (tumor, node, metastasis) tumorméret, nyirokcsomóstatus, távoli áttét; TP53 = tumorprotein-53; VSIG2 $=\mathrm{V}$-set and immunoglobulin domain containing $2 ; \mathrm{WHO}=$ (World Health Organization) Egészségügyi Világszervezet

A vastagbéldaganat $(\mathrm{CRC})$ kialakulásának hátterében az ismert „,klasszikus” adenoma-carcinoma szekvencia mellett az utóbbi két évtizedben egy másik, alternatív útvonal került felismerésre. Ezt az angol „serrated” meghatározás nyomán fogazott útvonalnak nevezzük [1]. Mára kiderült, hogy a klasszikusan ismert, Vogelstein által leírt modell a CRC-k hozzávetőleg 60-70\%-áért felelős, a fennmaradó 10-30\%-uk hátterében pedig a fogazott útvonal áll [2]. Az ezen az útvonalon kialakuló CRC a DNS-hiba javítása, a sejtciklus szabályozása és a DNSreplikáció során bekövetkező progresszív genetikai és epigenetikai módosulás következményeként jön létre. A CRC meglehetősen heterogén betegségcsoportot képez, melyet a tumor progresszióját elősegítő genetikai instabilitás jellemez. Ez az instabilitás geno- és fenotípusosan több úton is megnyilvánulhat, mint például a mikroszatellita-instabilitás (MSI), a kromoszomális instabilitás (CIN), illetve a CpG-sziget-metilációs fenotípus (CIMP). A molekuláris biológia fejlődésével mára a klasszikus klinikai és patológiai paraméterek mellett egyre több lehetőség nyílik a daganatos progresszió során létrejövő azon génhibák és hibás géntermékek megismerésére, amelyek a daganatok keletkezésében, növekedésében és terjedésében kulcsfontosságú szerepet játszanak. A fogazott útvonalon kialakuló laesiók korai felfedezése kihívást jelent a klinikusok számára, és a terápiás lehetőségek máig nagyrészt feltáratlanok. A hátterükben múködő mechanizmusok pontosabb feltérképezésével és megismerésével azonban az invazív daganatok egy részének kialakulása megelőzhető lehet, illetve a már kialakult CRC esetében lehetőség nyílhat a klinikai gyakorlatban alkalmazható, személyre szabott kezelés megválasztására.

\section{A CRC hátterében leggyakrabban tanulmányozott molekuláris genetikai eltérések és markerek}

\section{KRAS}

A KRAS onkogén alapvető szerepet játszik szignáltranszdukciós folyamatokban, számos növekedési faktor propagációjában, a sejtosztódásban, a sejtdifferenciációban és az apoptózisban. Mutációja a CRC-k kb. 30-40\%ában fordul elö, mind a klasszikus, mind a fogazott útvonalon kialakuló daganatokban megjelenhet [3]. A KRASmutáció a fogazott útvonalon kevésbé gyakori, mint a BRAF-mutáció, és általában CIMP-L-statusszal társul [4]. A KRAS klinikai jelentősége, hogy az EGFR-szignál negatív regulátoraként múködik, így aktiváló mutációja esetén az EGFR-t célzó terápiára a daganat rezisztens. Emiatt a KRAS-mutáció vizsgálata metasztatikus CRCben az anti-EGFR-terápia negatív prediktív markereként használható, illetve meghatározása egy szélesebb RASpanel áttekintésével ma már rutin klinikai gyakorlattá vált [5].

\section{MSI-instabilitás}

A „mismatch repair” (MMR) gének a DNS-nukleotid hibáinak felismerésére és kijavítására szolgálnak. Instabilitásuk a sporadikus daganatok között a leggyakrabban a vastagbél daganataiban fordul elö, amelyek 10-15\%ában kimutatható [6]. A magas mikroszatellita-instabilitást mutató daganatok (MSI-H) klinikai, patológiai és molekuláris jellemzői különböznek az alacsony mikroszatellita-instabilitású és mikroszatellita-stabil daganatokéitól (MSI-L/MSS): általában kevésbé agresszívek, a flexura lienalistól fóleg proximalisan helyezkednek el, sok esetben alacsonyan differenciáltak, mucinosus és kevert szövettani típusúak, jellegzetes peri- és intratumorális lymphoid sejtes infiltrációt mutatnak, és prognózisuk kedvezóbb [7].

\section{$B R A F$}

A BRAF protoonkogén a Ras/Raf/MEK jelátviteli útvonalon a KRAS negatív regulátoraként részt vesz a sejtproliferáció, -differenciáció, sejtmigráció és apoptózis szabályozásában. Mutációja a colorectalis daganatok kb. 5-15\%-ában fordul elő, és különösen jellemző a fogazott útvonalra. Ezen általában MSI-H és CIMP-H molekuláris statusszal társul [8]. MSS-vastagbéldaganatokban szignifikánsan rosszabb prognózist jelez, MSI-H-tumorokban azonban szerepe még vitatott. Feltételezhető, hogy a BRAF-mutáció nem önmagában felelős a rossz prognózisért, sokkal inkább attól a genetikai útvonaltól függ a hatása, amelyen kialakul [8]. 


\section{CIMP (metilációs fenotípus)}

A CpG-szigetek a humán gének hozzávetôleg 50\%-ának promóterében megtalálhatók, általában metilálatlan állapotban. A CpG-szigetek hipermetilációja következményeképpen jön létre a CpG-sziget-metilációs fenotípus, mely a kor elörehaladtával egyre több gént érinthet, fokozva ezzel a genetikai instabilitást és a daganatok kialakulásának valószínúségét [9]. Azokat a daganatokat, amelyek ezt a fenotípust hordozzák, CIMP-pozitívnak nevezzük - ez a pozitivitás a metilációs statustól függő́en lehet alacsony (CIMP-L) vagy magas (CIMP-H). A CIMP-útvonal a CRC-k hozzávetóleg 30\%-ában megjelenik, $\mathrm{s}$ a proximalis colontumorok $\mathrm{kb}$. 30-40\%-a, a distalis colon- és rectumtumorok 5-15\%-a CIMP-pozitív [10]. A CIMP-pozitív tumorok közel 90\%-ára jellemző a BRAF- vagy a KRAS-mutáció is [11].

\section{A CRC különböző felosztásai}

A vastagbéldaganat a heterogenitása miatt különböző szempontok alapján további alcsoportokba rendszerezhető (klinikai, driver gének, epigenetikai, genomikai, transzkripciós mintázat, stroma-immun mikrokörnyezet). Ezek közül az egyik az ún. molekuláris felosztás, melynek altípusait az MSI, a CIMP jelenléte, valamint a BRAF és a KRAS szomatikus mutációja határozza meg. Ezek alapján általában 3-6 alkategória látszik elkülönülni. Az egyik legismertebb a Jass és mtsai által 2007-ben kialakított 5 molekuláris alkategória: l. CIMP-H/MSI$\mathrm{H}$ /BRAF mutáció, 2. CIMP-H/MSI-L vagy MSS/ BRAF mutáció, 3. CIMP-L/MSI-L vagy MSS/KRAS mutáció, 4. CIMP-0/MSS, 5. MSI-H/CIMP-0 (Lynch-szindróma) [6]. A molekuláris felosztás mellett a genomikai analízis által meghatározott felosztás is létrejött, melyet a 2012-ben publikált „The Cancer Genome Atlas Project" (TCGA) osztályozása reprezentál. Ennek alapján hipermutált (kb. 16\%) és nem hipermutált (kb. 84\%) CRC-altípusok különíthetők el [12]. Egy 2015-ben megjelent nemzetközi tanulmány (Consensus Molecular Subtypes [CMS] Consortium) 6 kutatócsoport adatait feldolgozva, a már korábban meghatározott különféle alcsoportok között keresve összefüggést, génexpressziós mintázatok alapján alakított ki 4 altípust. Ezek az MSI-immun (CMS-1, 14\%), a kanonikus (CMS-2, 37\%), a metabolikus (CMS-3, 13\%) és a mesenchymalis altípus (CMS-4, 23\%). Ezeken kívül egy kevert, nem klasszifikált csoportot is megjelölt a fenti kategóriákba nem sorolható esetekre (13\%) [13]. Ma ez utóbbit tekintjük az egyik legátfogóbb és legmodernebb felosztásnak. A colorectalis daganat molekuláris, genom- és génexpressziós analízis alapján történő, különbözố altípusokba való besorolásait az 1. táblázat foglalja össze.

\section{A prekurzor és invazív daganatok kialakulásának hátterében álló molekuláris eltérések, útvonalak}

\section{Klasszikus útvonal}

Klasszikus útvonalnak nevezzük azt a legrégebben ismert genetikai modellt, melyben az adenoma-dysplasiacarcinoma szekvencia során a normálnyálkahártyából meghatározott genetikai módosulások kaszkádja révén benignus adenoma, high-grade dysplasiát mutató adenoma, végül invazív colorectalis adenocarcinoma jön létre [14]. Ezen az útvonalon jellemző az APC tumorszuppresszor gén inaktiválódása, a Wnt jelátviteli útvonal aktivációja, a KRAS onkogén mutációja, a 18q21 régió (heterozigótaság) elvesztése és a TP53 gén funkcióvesztő mutációja [15]. Ezen daganatok az összes vastagbélrák kb. 60\%-át képviselik. A klasszikus útvonal daganatait kromoszomális instabilitás (CIN) jellemzi, és jelentôs génkópiaszám-variáció figyelhetô meg bennük [16]. Általában CIMP-0, MSI-L vagy MSS-ek, kb. 40\%-ban hordoznak KRAS-mutációt [6]. A kromoszomálisan instabil daganatok génexpressziós mintázatukat tekintve három alcsoportba különülnek el (CMS-2-4) [17] (1. ábra).

\section{Az úgynevezett ,fogazott” (serrated) útvonal}

A fogazott útvonalon kialakuló vastagbéldaganat hátterében genetikai és epigenetikai (metiláció, hisztonmodifikáció) módosulások kaszkádja áll. A daganatok hozzávetóleg 10-30\%-a alakul ki ezen az útvonalon [2]. A molekuláris felosztást követve, általában CIMP-H/MSIH/BRAF-mutáns; CIMP-H/MSI-L vagy MSS/BRAFmutáns; CIMP-L/MSI-L vagy MSS/KRAS-mutáns karakterisztikával rendelkeznek [6]. Idesorolható a genomikai analízis alapján kialakított hipermutált alcsoport [12], illetve a génexpressziós mintázat alapján elkülönülő CMS-1 altípus [13] (1. ábra). A különböző felosztások szerinti fogazott altípusokat az 1. táblázat sárgával megjelölt cellái szemléltetik.

\section{A fogazott útvonal laesióinak makroszkópos, mikroszkópos megjelenése és morfológiája}

A fogazott útvonalon kialakuló laesiók molekuláris tulajdonságaikon felül endoszkópos, makroszkópos, szövettani jellegzetességeikben, malignus potenciáljukban és progresszióhajlamukban is eltérnek a konvencionális laesióktól, ezért felismerésük és elkülönítésük már a korai stádiumban fontos. Az endoszkópia során általában a jobb colonfélben lelhetők fel, szesszilis vagy lapos, a nyálkahártyából alig előemelkedő vagy abba akár be is mélyedő elváltozások. Határuk bizonytalan, alakjuk aszimmetrikus, színük nagyon hasonló a környező mucosáéhoz. Mikroszkópos képükre hosszanti metszlapon 


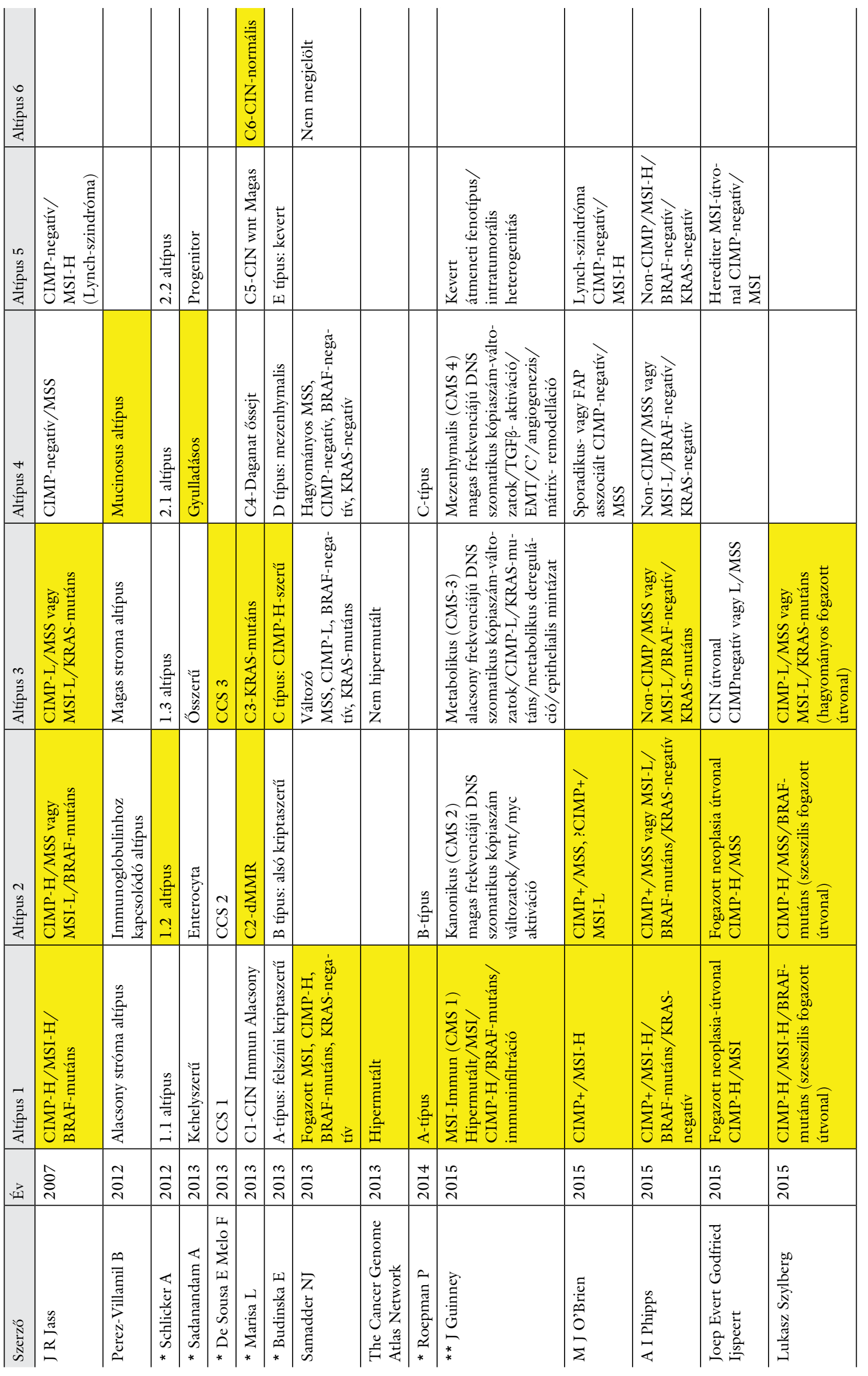

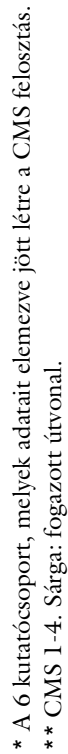




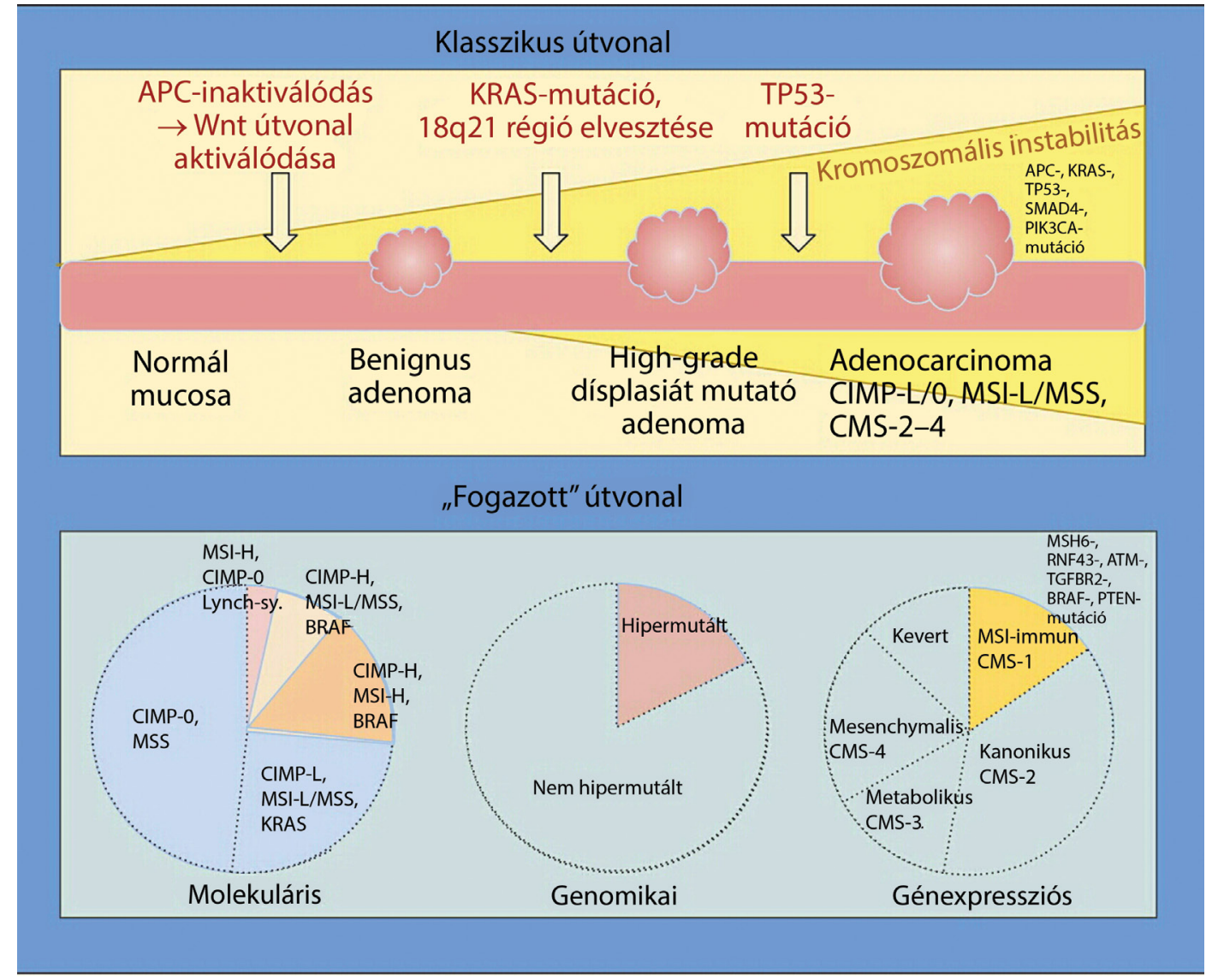

1. ábra

A „,klasszikus” és „fogazott” útvonal hátterében múködő genetikai és molekuláris eltérések, illetve a „fogazott” útvonal daganatainak a különböző felosztások szerinti eloszlása

fürészfogszerú (melyről a serrated elnevezést kapta), haránt metszeten csillag alakú mintázat jellemző. Ezt a jellegzetes mintázatot az apoptózisgátlás révén a kriptákban lévő nem proliferáló sejtek felhalmozódása okozza [18]. Fogazott laesiók immunhisztokémiailag fokozott expressziót mutatnak az ANXA10, CLDN18, CTSE, MUC5AC, MUC6, TFF2 és VSIG2 markerekkel a konvencionális adenomáktól eltérően [19].

\section{A nem invazin, úgynevezett prekurzor laesiók}

A 2010-ben megalkotott és máig alkalmazott WHOklasszifikáció a sporadikus fogazott polipokat 3 csoportba sorolja, melyek: 1. hiperplasztikus polip (HP), 2. szesszilis fogazott adenoma (SSA), 3. tradicionális fogazott adenoma (TSA) [20].

\section{Hiperplasztikus polip (HP)}

A leggyakoribb fogazott elváltozás (80-90\%), a reszekált vastagbélpolipok 25-30\%-a [21]. Az 50-60 éves korosztályt érinti a leginkább, nem rendelkezik malignus potenciállal [22]. Distalis lokalizáció (rectosigmoidalis bélszakasz) és $5 \mathrm{~mm}$-nél kisebb méret jellemzi, előfordulása a proximalis colonfélben nagyon ritka [23]. Magas kockázatú kategóriába akkor tartozik, ha több mint 20 elvál- tozás áll fenn, ha mérete nagyobb $10 \mathrm{~mm}$-nél, ha a proximalis bélszakaszban helyezkedik el, illetve ha a beteg családi anamnézisében CRC előfordult [24]. Az epithelialis mucintartalom alapján további 3 kategóriába: 1. microvesicularis (melyben BRAF-mutáció gyakori), 2. kehelysejtgazdag (melyben KRAS-mutáció kb. 50\%ban fordul elő) és 3. mucinszegény altípusokba sorolható [21]. Ezen alcsoportoknak a klinikai gyakorlatban egyelőre nincs jelentőségük.

\section{Szesszilis fogazott adenoma/polip (SSA/P)}

A fogazott laesiók kb. 5-25\%-a, a reszekált polipok hozzávetóleg 1,7-12,1\%-a [25, 26]. Morfológiailag hasonló a HP-hez, viszont igen magas malignus potenciállal bír, ami miatt elkülönítésük igen lényeges már a korai stádiumban [27]. Utóbb megbízható eredményeket értek el a differenciáldiagnosztikában a Workgroup serrAted polypS and Polyposis (WASP-) klasszifikációval [28]. Morfológiailag a SSA/P általában nagyobb ( $>10 \mathrm{~mm})$, a normálnyálkahártyánál halványabb színú és attól bizonytalan széllel elkülönülő elváltozás, mely főként a jobb colonfélre lokalizálódik. Sárgás vagy rozsdaszínú nyáksapka boríthatja, melyet a székletből és epesókból származó elszíneződés okoz. Mikroszkóposan a kripta teljes hosszában lévő fogazottság jellemző [27]. Ez azért lé- 
nyeges, mert a szövettani mintavétel során az elváltozás felszínéról származó minták esetében a diagnózis nem minden esetben adható meg, és a HP-tól való differenciáldiagnosztikai pontosság ilyen esetben kérdéses [29]. Molekulárisan a CIMP-H és az MSI jellemző, és gyakori a BRAF-mutáció is [22]. A CRC kialakulásának kockázata az elváltozások száma, lokalizációja, mérete és szövettani jellemzői alapján határozható meg.

\section{SSA dysplasiával (SSA-D)}

Gyorsabb növekedést mutat a konvencionális adenománál, illetve átlagosan háromszor gyorsabban növekszik, mint a dysplasiát nem mutató SSA/P. Ezenfelül agresszívebb viselkedésü, és magasabb kockázatot jelent malignus elfajulásra [21].

\section{Tradicionális serrated adenoma (TSA)}

A legritkább fogazott laesio, a colorectalis polipok $\mathrm{kb}$. 0,56-1,9\%-a [30]. Előfordulása a 6-7. életévtizedben a leggyakoribb. Malignus potenciálja magas, agresszív CRC prekurzor laesio [31]. Endoszkóposan inkább a distalis colonfélben található, fenyőtoboz- vagy páfrányszerű képet mutató, átlagosan 9-14 mm-es elváltozás. Fő diagnosztikai jellegzetessége a protuberáns vagy villiform növekedés, az ectopiás kriptaformáció, az eozinofil citoplazma és a luminális fogazottság [31]. Fogazott és adenomatosus dysplasia is előfordulhat bennük, mely előbbire a BRAF-mutáció és CIMP-H, míg az utóbbira a KRAS-mutáció és CIMP-L jellemző [31]. A TP53mutáció közel 50\%-ban mutatható ki [32]. Immunhisztokémiailag a MUC2-, MUC5AC- és $\beta$-kateninexpresszió gyakori [32].

\section{Kevert polip}

Az összes CRC prekurzor laesio (beleértve a konvencionális adenomát is) legalább két jellegzetességét együttesen mutató elváltozásokat soroljuk ebbe az alkategóriába. Gyakorisága az összes colonpolip 0,7-1,5\%-a, a fogazott laesiók 1,7-4,7\%-a [29, 33].

\section{A fogazott colorectalis carcinoma}

A fogazott CRC jellegzetes szövettani és molekuláris karakterisztikával rendelkezik, mely alapján elkülöníthető a klasszikus adenoma-carcinoma szekvenciát követő daganatoktól. A fogazott CRC legtöbb strukturális és citológiai jellemzője a DNS-metilációval áll összefüggésben. Meg kell jegyezni azonban, hogy a fogazott útvonalon fejlődő adenocarcinomák közül nem mindegyik mutat végül fogazott szövettani jellegzetességeket [34]. A fogazott CRC szövettani kritériumai a kripta epitheliumának fogazott mintázata; a szitaszerü, csipkézett és trabecularis szerkezet; az intracelluláris és gyakran jelentős extracelluláris mucinszekréció; az alacsony mag/citoplazma arány, nagy, kerek vagy ovális vesicularis sejtmagok; a prominens magi membrán (kromatinkondenzáció a membránban), a megőrzött magpolaritás és az eozinofil citoplazma [6].

A fogazott útvonalat a molekuláris felosztást követve a Jass-féle klasszifikáció szerinti 1-3-as CRC-altípusok képviselik. Az 1-2-es típusok prekurzor laesiói a fogazott polipok, a 3-as típus mind a fogazott, mind a klasszikus adenomából kialakulhat. Az 1-2-es típusú CRC a proximalis colonfélben gyakoribb, általában mucinosus szövettani megjelenés jellemzi, alacsonyan differenciált, fürészfogszerü mintázatot mutat, és jelentős lymphocytainfiltráció jellemzi. A 3-as altípusú CRC inkább a distalis colonfélre lokalizálódik, aneuploid, magasabban differenciált és kevésbé kifejezett fogazottságot mutat [6].

\section{Prognózis}

Ma a klinikumban alkalmazott prognosztikus faktor a daganat anatómiai kiterjedése és szövettani differenciáltsági foka. Megfigyelhető azonban, hogy azonos szövettani stádiumok esetén is igen változatos kórlefolyással számolhatunk. A daganat molekuláris biológiai tulajdonságai is prognosztikus potenciállal bírnak, ezért született számos vizsgálat az elmúlt években a molekuláris markerek azonosítására és minél pontosabb megismerésére [35]. Ezenfelül a mikrokörnyezeti faktorok szerepére is fény derült [36]. A várható prognózis felmérése segíthet elkerülni az esetleges túl- vagy alulkezelést, illetve meghatározni az utánkövetés gyakoriságát. Általánosságban a fogazott útvonalon kialakuló vastagbéldaganat agreszszívebb viselkedésű és rosszabb prognózisú, mint a klaszszikus útvonalon létrejövő CRC. Több vizsgálatban az OS és a DFS - és néhány vizsgálatban a CSS tekintetében is - a molekuláris besorolás szerinti 2-es típusú (CIMPH/MSI-L/MSS) daganatok bizonyultak a legkedvezőtlenebb prognózisúnak, melyek a fogazott útvonal képviselői [37]. Az egyes biomarkereket külön vizsgálva az MSI-H-fenotípus önmagában számos vizsgálatban kedvező prognosztikai faktornak bizonyult. A BRAF-mutáció prognosztikus szerepe feltételezhetően függ a kialakulási útvonaltól [8]. A CIMP fenotípus prognosztikus szerepe egyelőre ellentmondásos: egyrészt független negatív prognosztikus faktornak bizonyult különböző CRC-altípusok esetén, viszont a vele együttesen fennálló genetikai faktorok befolyásolhatják a hatását, mint pl. az MSI és a KRAS/BRAF status [38]. A KRAS 12-es kodonmutációit összefüggésbe hozták a daganat progreszsziójával [39]. Más vizsgálatban viszont II-III-as stádiumú CRC-ben a KRAS-statusnak nem volt prognosztikus szerepe [8]. A molekuláris tulajdonságokon túl, a fogazott laesiók rosszabb prognózisát az is elősegítheti, hogy makroszkópos karakterisztikájuk miatt, fóleg korai stádiumban, nehezen vehetők észre. Ez fóként a jobb colonfelet érinti, mivel ott gyakoribb a fogazott elváltozás [40]. Erre példa egy 346 polipectomiát összegző vizsgálat eredménye, melyben az inkomplett endoszkópos reszekció kockázata jelentősen magasabb volt SSA/P $(31,0 \%)$, mint klasszikus adenoma $(7,2 \%)$ esetén [41]. A 
korai stádiumban nem detektált laesiók tehetők felelőssé továbbá az ún. intervallumcarcinomák kialakulásáért is [42]. A molekuláris biológiai viselkedés feltáratlan tényezői, a korai felismerés/eltávolítás technikai nehézségei mellett az egyes adjuváns kezelésekre adott eltérő válaszkészség is hozzájárul a fogazott laesiók rosszabb prognózisához.

\section{Terápia}

A legtöbb CRC elsődleges kezelése a daganat sebészi eltávolítása. Ezt meghatározott esetekben neoadjuváns és/vagy adjuváns terápia egészíti ki. Az elmúlt években a CRC kemoterápiás kezelésének alapelvei különböző fázisokon mentek keresztül. Kezdetben azon driver mutációk és genetikai módosulások megismerése, amelyek a terápiás válaszban szerepet játszanak, alakították ki az „egy gén, egy kemoterápiás szer” szemléletet. Erre példa az anti-EGFR-terápiára való rezisztencia KRAS-mutáns daganatok esetén. Ezt követően jött létre az ún. „több gén, kombinált kemoterápia” elmélet, ahogy a CRC-genom tér- és időbeli heterogenitása és a terápiás választ befolyásoló egyéb események (mint pl. a klonális szelekció) ismertté váltak. A transzkripciós felosztás szerinti CRC-altípusok létrejötte, a tumor-, stroma- és immunológiai komponensek szerepének egyre pontosabb megismerése viszont egyre inkább a „,multimolekuláris, kombinált kemoterápia” szemlélet felé irányította a figyelmet [17].

Jelenleg a nem metasztatikus CRC különböző altípusait célzó terápiára nincs rutinszerú klinikai gyakorlat. A biomarkerek tekintetében a legjobb eredményeket a KRAS-mutációval érték el, mely jelenleg független prediktív markere az anti-EGFR-terápiának metasztatikus CRC esetén [43]. A CRC immunhisztokémiai és/vagy PCR-vizsgálata a mikroszatellita-instabilitás szúrésére gyakorlatban van a Lynch-szindróma kizárására [44]. Emellett a többi biomarkerrel kapcsolatban is születtek különböző eredmények, melyek részben még ellentmondásosak, és egyelőre nem alkalmazhatók megbízhatóan a rutin klinikai gyakorlatban [45]. Az utóbbi időben elfogadott, miszerint az MSI-fenotípusú II-III. stádiumú CRC-k nem reagálhatnak jól az 5-fluorouracil (5-FU)-alapú kemoterápiára (illetve II-es stádiumú CRC esetén még hátrányos is lehet) [46]. Az MSI-daganatok 20-szor gyakoribb mutációs mértéke (hipermutáltsága) felveti a kérdést, hogy ezen tulajdonságuk miatt esetleg terápiásan célozhatók lennének. Egy 2015-ben publikált adat szerint az MSI-H-daganatok jól reagáltak „programozott halál-1-es" immunellenőrzésipont-gátló (pembrolizumab-) terápiára az MSS-daganatokkal ellentétben [47]. További vizsgálatok folynak különféle immunellenőrzésipont-inhibitorokkal szemben is ebben a betegcsoportban [45]. A Schlicker és mtsai által leírt 1.2-es altípusú CRC (melyben MSI és lymphocytainfiltráció jellemző) magas érzékenységet mutatott továbbá a glikogén-szintáz-kináz, a c-Src és a Wnt-szignál inhibitoraival szemben [48]. A biomarker-vizsgálatokon túl a transzkripciós mintázatok és a CRC különböző immunaktivációs profiljainak, mikrokörnyezeti tényezőinek feltérképezése további lehetôségeket biztosíthat a célzott kezelésre [17].

\section{Utánkövetés}

Fogazott adenoma eltávolítását követően a kolonoszkópos utánkövetési időt az elváltozás(ok) fajtája, nagysága, száma és SSA/P esetén dysplasia jelenléte határozza meg. Az utánkövetési irányelvek akkor alkalmazhatók optimálisan, ha az eltávolítás teljesen az épben történik. Alacsony rizikójú SSA/P (dysplasia nélküli, <10 mm) 3-5 éves utánkövetése javasolt 1 db laesio esetén és 1-5 éves utánkövetése 1-nél több laesio esetén. A magas rizikójú SSA/P (<3 elváltozás, de $\geq 10$ mm vagy SSA-D) esetén 1-3 év múlva a kolonoszkópia megismétlése javasolt. Fogazott polyposis szindróma esetén az éves utánkövetés ajánlott [49]. A < 10 mm-es HP-kat 10 évente, a TSA-kat 3 évente érdemes utánkövetni [50]. A fogazott és a klasszikus útvonalon kialakuló CRC utánkövetése között jelenleg nincs különbség.

\section{Túlélés}

A fogazott útvonal daganatai között az MSI-H-fenotípussal rendelkező tumorok túlélése bizonyult a legkedvezőbbnek. Az MSI-fenotípus önmagában is kedvező a túlélés szempontjából az MSS-daganatokhoz képest [7]. Korábbi vizsgálatok igazolják, hogy az MSI-daganatok jellegzetes peri- és intratumorális lymphoid sejtes infiltrációt mutatnak. Ez a lymphocytabeszürődés és főként a CD8+ lymphocyták jelenléte szerepet játszhat e daganatok jobb prognózisában [51]. A CIMP-H/MSI-L vagy MSS/BRAF-mutáns molekuláris altípus túlélése kedvezőtlennek bizonyult [37]. A relapsust követő túlélés tekintetében a konszenzusi CMS-2-es alcsoportban jó eredményeket tapasztaltak, míg a CMS-1-es alcsoportnak kedvezőtlen túlélése volt [52].

\section{Következtetés}

A colorectalis daganatra ma már heterogén betegségként tekintünk. A hátterében múködő genetikai tényezók, molekuláris eltérések, kialakulási útvonalak, mikrokörnyezeti és környezeti faktorok, illetve az ezek közötti összefüggések csak részben ismertek. Felmerül a kérdés, hogy ezek pontosabb megismerése létrehozhat-e hatékonyabb szürési rendszert, illetve hogy az egyes daganattípusok sajátosságainak felmérése által személyre szabott, célzott terápia lehetővé válhat-e a közeljövőben. 
Anyagi támogatás: A cikk a Bolyai János Kutatási Ösztöndíj támogatásával készült.

Szerzői munkamegosztás: Á. E. I.: A kézirat megírása, összeállítása, szerkesztése. H. E., Gy. B., H. L.: A kézirat javítása. Sz. A. M.: A kézirat javítása, a téma kidolgozása. A cikk végleges változatát valamennyi szerző elolvasta és jóváhagyta.

\section{Érdekeltségek: A szerzóknek nincsenek érdekeltségeik.}

\section{Irodalom}

[1] Vogelstein B, Fearon ER, Hamilton SR, et al. Genetic alterations during colorectal-tumor development. N Engl J Med. 1988; 319: 525-532.

[2] JE IJ, Medema JP, Dekker E. Colorectal neoplasia pathways: state of the art. Gastrointest Endosc Clin N Am. 2015; 25: 169182 .

[3] Imamura Y, Lochhead P, Yamauchi M, et al. Analyses of clinicopathological, molecular, and prognostic associations of KRAS codon 61 and codon 146 mutations in colorectal cancer: cohort study and literature review. Mol Cancer 2014; 13: 135.

[4] Hinoue T, Weisenberger DJ, Lange CP, et al. Genome-scale analysis of aberrant DNA methylation in colorectal cancer. Genome Res. 2012; 22: 271-282.

[5] Benvenuti S, Sartore-Bianchi A, Di Nicolantonio F, et al. Oncogenic activation of the RAS/RAF signaling pathway impairs the response of metastatic colorectal cancers to anti-epidermal growth factor receptor antibody therapies. Cancer Res. 2007; 67: $2643-2648$

[6] Jass JR. Classification of colorectal cancer based on correlation of clinical, morphological and molecular features. Histopathology 2007; 50: 113-130

[7] Popat S, Hubner R, Houlston RS. Systematic review of microsatellite instability and colorectal cancer prognosis. J Clin Oncol. 2005; 23: 609-618 .

[8] Roth AD, Tejpar S, Delorenzi M, et al. Prognostic role of KRAS and $B R A F$ in stage II and III resected colon cancer: results of the translational study on the PETACC-3, EORTC 40993, SAKK 60-00 trial. J Clin Oncol. 2010; 28: 466-474

[9] Wong IH. Methylation profiling of human cancers in blood: molecular monitoring and prognostication (review). Int J Oncol. 2001; 19: 1319-1324.

[10] Hughes LA, Khalid-de Bakker CA, Smits KM, et al. The CpG island methylator phenotype in colorectal cancer: progress and problems. Biochim Biophys Acta 2012; 1825: 77-85.

[11] Moussata D, Boschetti G, Chauvenet M, et al. Endoscopic and histologic characteristics of serrated lesions. World J Gastroenterol. 2015; $21: 2896-2904$.

[12] Cancer Genome Atlas N. Comprehensive molecular characterization of human colon and rectal cancer. Nature 2012;487: 330-337.

[13] Guinney J, Dienstmann R, Wang X, et al. The consensus molecular subtypes of colorectal cancer. Nat Med. 2015; 21: 13501356.

[14] Fearon ER, Vogelstein B. A genetic model for colorectal tumorigenesis. Cell 1990; 61: 759-767.

[15] Zoratto F, Rossi L, Verrico M, et al. Focus on genetic and epigenetic events of colorectal cancer pathogenesis: implications for molecular diagnosis. Tumour Biol. 2014; 35: 6195-6206.

[16] Bosman FT, Yan P. Molecular pathology of colon cancer. Pol J Pathol. 2014; 65(Suppl 1): S1-S11.

[17] Dienstmann R, Vermeulen L, Guinney J, et al. Consensus molecular subtypes and the evolution of precision medicine in colorectal cancer. Nat Rev Cancer 2017; 17: 79-92.
[18] O'Brien MJ. Hyperplastic and serrated polyps of the colorectum. Gastroenterol Clin North Am. 2007; 36: 947-968.

[19] Bae JM, Kim JH, Kang GH. molecular subtypes of colorectal cancer and their clinicopathologic features, with an emphasis on the serrated neoplasia pathway. Arch Pathol Lab Med. 2016; 140: 406-412.

[20] Bosman FT, World Health Organization, International Agency for Research on Cancer. WHO classification of tumours of the digestive system. 4th edn. International Agency for Research on Cancer, Lyon, 2010.

[21] Bettington M, Walker N, Clouston A, et al. The serrated pathway to colorectal carcinoma: current concepts and challenges. Histopathology 2013; 62: 367-386.

[22] Rex DK, Ahnen DJ, Baron JA, et al. Serrated lesions of the colorectum: review and recommendations from an expert panel. Am J Gastroenterol. 2012; 107: 1315-1329.

[23] Rex DK, Ulbright TM. Step section histology of proximal colon polyps that appear hyperplastic by endoscopy. Am J Gastroenterol. 2002; 97: 1530-1534.

[24] Jass JR. Hyperplastic polyps of the colorectum - innocent or guilty? Dis Colon Rectum 2001; 44: 163-166.

[25] Langner C. Serrated and non-serrated precursor lesions of colorectal cancer. Dig Dis. 2015; 33: 28-37.

[26] Bettington M, Walker N, Rosty C, et al. Critical appraisal of the diagnosis of the sessile serrated adenoma. Am J Surg Pathol. 2014; 38: 158-166.

[27] Singh R, Zorrón Cheng Tao Pu L, Koay D, et al. Sessile serrated adenoma/polyps: Where are we at in 2016? World J Gastroenterol. 2016; 22: 7754-7759.

[28] IJspeert JE, Bastiaansen BA, van Leerdam ME, et al. Development and validation of the WASP classification system for optical diagnosis of adenomas, hyperplastic polyps and sessile serrated adenomas/polyps. Gut 2016; 65: 963-970.

[29] Bateman AC. Pathology of serrated colorectal lesions. J Clin Pathol. 2014; 67: 865-874.

[30] Bettington ML, Chetty R. Traditional serrated adenoma: an update. Hum Pathol. 2015; 46: 933-938.

[31] Chetty R. Traditional serrated adenoma (TSA): morphological questions, queries and quandaries. J Clin Pathol. 2016; 69: 6-11.

[32] Bettington ML, Walker NI, Rosty C, et al. A clinicopathological and molecular analysis of 200 traditional serrated adenomas. Mod Pathol. 2015; 28: 414-427.

[33] Yamane L, Scapulatempo-Neto C, Reis RM, et al. Serrated pathway in colorectal carcinogenesis. World J Gastroenterol. 2014; 20: 2634-2640.

[34] Rhee YY, Kim KJ, Kang GH. CpG island methylator phenotypehigh colorectal cancers and their prognostic implications and relationships with the serrated neoplasia pathway. Gut Liver 2017; 11: 38-46.

[35] Samadder NJ, Vierkant RA, Tillmans LS, et al. Associations between colorectal cancer molecular markers and pathways with clinicopathologic features in older women. Gastroenterology 2013; 145: 348-356.

[36] Tosolini M, Kirilovsky A, Mlecnik B, et al. Clinical impact of different classes of infiltrating $\mathrm{T}$ cytotoxic and helper cells (Thl, Th2, Treg, Th17) in patients with colorectal cancer. Cancer Res. 2011; 71: 1263-1271.

[37] Phipps AI, Limburg PJ, Baron JA, et al. Association between molecular subtypes of colorectal cancer and patient survival. Gastroenterology 2015; 148: 77-87.e2.

[38] Juo YY, Johnston FM, Zhang DY, et al. Prognostic value of CpG island methylator phenotype among colorectal cancer patients: a systematic review and meta-analysis. Ann Oncol. 2014; 25: 2314-2327.

[39] Russo A, Bazan V, Agnese V, et al. Prognostic and predictive factors in colorectal cancer: Kirsten Ras in CRC (RASCAL) and 
TP53CRC collaborative studies. Ann Oncol. 2005; 16(Suppl 4): iv44-iv49.

[40] Kaminski MF, Regula J, Kraszewska E, et al. Quality indicators for colonoscopy and the risk of interval cancer. N Engl J Med. 2010; 362: 1795-1803

[41] Pohl H, Srivastava A, Bensen SP, et al. Incomplete polyp resection during colonoscopy - results of the complete adenoma resection (CARE) study. Gastroenterology 2013; 144: 74-80.

[42] Pohl H, Robertson DJ. Colorectal cancers detected after colonoscopy frequently result from missed lesions. Clin Gastroenterol Hepatol. 2010; 8: 858-864.

[43] Vecchione L, Jacobs B, Normanno N, et al. EGFR-targeted therapy. Exp Cell Res. 2011; 317: 2765-2771.

[44] Burt RW. Diagnosing Lynch syndrome: more light at the end of the tunnel. Cancer Prev Res. (Phila.) 2012; 5: 507-510.

[45] Graham DM, Coyle VM, Kennedy RD, et al. Molecular subtypes and personalized therapy in metastatic colorectal cancer. Curr Colorectal Cancer Rep. 2016; 12: 141-150.

[46] Sargent DJ, Marsoni S, Monges G, et al. Defective mismatch repair as a predictive marker for lack of efficacy of fluorouracilbased adjuvant therapy in colon cancer. J Clin Oncol. 2010; 28: 3219-3226.
[47] Le DT, Uram JN, Wang H, et al. PD-1 blockade in tumors with mismatch-repair deficiency. N Engl J Med. 2015; 372: 25092520 .

[48] Schlicker A, Beran G, Chresta CM, et al. Subtypes of primary colorectal tumors correlate with response to targeted treatment in colorectal cell lines. BMC Med Genomics 2012; 5: 66.

[49] Bordaçahar B, Barret M, Terris B, et al. Sessile serrated adenoma: from identification to resection. Dig Liver Dis. 2015; 47: 95102.

[50] Lieberman DA, Rex DK, Winawer SJ, et al. Guidelines for colonoscopy surveillance after screening and polypectomy: a consensus update by the US Multi-Society Task Force on Colorectal Cancer. Gastroenterology 2012; 143: 844-857.

[51] Carethers JM, Murali B, Yang B, et al. Influence of race on microsatellite instability and CD8+ T cell infiltration in colon cancer. PLoS ONE 2014; 9: el00461

[52] Müller MF, Ibrahim AE, Arends MJ. Molecular pathological classification of colorectal cancer. Virchows Arch. 2016; 469: $125-134$.

(Ágoston Emese Irma dr., Kecskemét, Klapka u. 17/A, 1/2., 6000 e-mail: emeseagoston@gmail.com)

\section{MEGHÍVó}

\section{A Szent János Kórház és Észak-budai Egyesített Kórházak Tudományos Bizottsága}

tisztelettel meghivja az érdeklődőket a következő tudományos ülésére.

Időpont: 2018. február 22. (csütörtök) 14 óra

Helyszín: Szent János Kórház Auditóriuma - 1125 Budapest, Diós árok 1-3.

Téma: „Mentális betegségek és határterületeinek ellátása interdiszciplinális szemléletben”

Üléselnök: Dr. Jánosi András

\section{Program:}

Kurimay Tamás dr., Németh Tünde dr. és az „EGYÜTT” Team:

A perinatális depresszió ellátásának aktuális kérdései

20 perc

Kőpájer Gabriella dr., Urbán Ágnes, Soós Gergely dr., Pálfy Anett (Gyermekosztály),

Kurimay Tamás dr:: Állatasszisztált terápiák lehetöségei a Szent János Kórházban

20 perc

Barkaszi Bernadett dr., Kapócs Gábor dr., Kósik-Csorba Gabriella dr., Kurimay Tamás dr.:

Időskori mentális zavarok és ellátásuk a kapcsolati pszichiátriai szemléletben.

Időskori zavartság és ellátásának néhány gyakorlati problémája

20 perc

Gombos Katalin dr. (Szemészeti Osztály): Szemészeti betegek mütéti elökészitésének

új módszerei

20 perc

Minden érdeklődőt szeretettel várunk. 